\title{
Review of Jonathan Israel, The Expanding Blaze. How the American Revolution Ignited the World, 1775-1848, Princeton: Princeton University Press, 2017, 755 pp, HB
}

\author{
Karen Green \\ School of Historical and Philosophical Studies, University of Melbourne, AU \\ karen.green@unimelb.edu.au
}

Keywords: radical enlightenment; American Revolution; French Revolution; democracy; pantheism; republicanism

Although Israel's latest monumental book is called 'the expanding blaze' it might more aptly have been titled, 'the flickering flame', for it tells the story of the very checkered history of the ideals of democratic republicanism in the lead-up to the French Revolution and in the Caribbean, Central and South America, and Europe during the sixty years following it. As with his earlier histories, this one is structured around the opposition between radical and moderate enlightenment projects, and much of the story focuses on the failure of the heroes of the account, the advocates of radical, democratic republicanism, to win out against the forces of conservatism, monarchism, and counter-enlightenment.

The first half of the book concentrates on the lead-up to and aftermath of the American Declaration of Independence, and the conflict which emerged between those like John Adams, who were in favor of government by a propertied elite, and supporters of a more thoroughly democratic republicanism committed to a broad or universal male suffrage. Although Israel emphasizes the importance of ideas in the genesis of these conflicts, as developed by journalists, academics, students, and literary individuals, he does not in general delve deeply into the texts or arguments developed. He rejects the views of those, in particular Hannah Arendt $(23,602)$, who would see the French and American revolutions as fundamentally different in character, and, proposing that one should characterize the 'radical Enlightenment' as 'democratic republicanism combined with rejection of religious authority', he argues that, until the Terror, the French Revolution was grounded in the same republican ideology as the American and played out the same clash between "moderates" venerating Locke, Montesquieu, and British "mixed government"' and democratic republicans who were fighting for 'secularism and universal and equal human rights' (17). He presents a compelling case for the influence of many of the same individuals, issues, and conflicts being operative on both sides of the Atlantic. However, I found his characterization of the philosophical positions insufficiently nuanced and his assumption that the moderates constituted a reactionary response to a fundamentally radical impetus, emanating from America but rooted in the works of French philosophes (themselves ultimately heirs of Spinoza) unconvincing. Initially, 
colonial dissatisfaction with the British government was couched in terms of the complaints of loyal subjects of the crown, who wished a restoration of abrogated rights. In France also, as Germaine de Staël's narrative in Considerations on the Principle Events of the French Revolution argues, it is plausible to conclude that a moderate attempt to reform the French monarchy, along the lines of the British, spiraled out of control in the face of myriad conflicting interests.

Israel is a historian rather than a philosopher, and the strength of this book lies in the narrative accounts he provides of the many abortive 'revolutions' in Haiti, Ireland, Spain, Latin America, France, Italy, and Germany during the period and the links between the people and ideas that were at play in them. Some of the most engaging chapters are devoted to the activities and influence of single individuals-Adams, Franklin, and Jefferson-the last of whom, because of his secularism, emerges as a hero of Israel's account (11). This is despite the fact that Jefferson caved in to the first fundamental hypocrisy of the American Revolution, the failure to abolish slavery (141), and showed himself to be essentially a Lockean in relation to Native Americans' rights to land (171). Israel provides a short chapter on the abject failure of the founders of the United States to apply the principle of equal rights to slaves (140-157) and only briefly mentions their dereliction in relation to women in a passage that repeats the popular proposal that the first champions of women's emancipation were Olympe de Gouges and Mary Wollstonecraft, thus effacing hundreds of years of years of the female struggle for respect (275). Nor does he consider that, insofar as the colonists' attitude toward slavery was only seen to be rank hypocrisy by a small minority-many of whom were religiously inspired-the failure of the proponents of American independence to consider the rights of any but property-owning, white men fits in well with traditional histories, according to which the demand for independence was grounded in the fundamentally Lockean principle of a right to property free of the depredations of a Crown bent on taxation (or excise) without parliamentary representation, rather than on noble principles promoting the general equality of all mankind. The fuse that sparked the events leading to American independence was the Stamp Act; opposition to it and to Britain's heavy-handed customs collectors was largely economic rather than deeply philosophic. The Americans would have been happy to have accepted a restoration of their assemblies' earlier direct relationship to the Crown and a right to determine for themselves how they were taxed had George III and his ministry been sufficiently far-sighted to have allowed them.

In general, the narrative is marred by Israel's attempt to shoehorn all participants into his favourite dichotomy, rather than recognizing that the intellectual background of the revolutions was a tangled mess of self-interest mixed with enlightened arguments and conflicting ideologies. Individuals who agreed on metaphysical issues could wildly disagree on political principles and vice versa. His determination to carry through his association of democratic republicanism with secularism and his insistence that the influence of Locke has been overplayed also prevent him from recognising that there are conflicting elements within Locke's outlook as well as in that of others. For instance, Locke's commitment to rational religion, the rational demonstrability of moral principles, and the equality of humans as God's creatures was central to the influential democratic republicanism of Catharine Macaulay from the 1760s. Her understanding of political progress towards republican government as part of God's providential plan for universal happiness was shared by many dissenters and by her friend Mercy Otis Warren, whose 1805 History of the Rise, Progress and Termination of the American Revolution is completely ignored by Israel. This is despite the fact that she was an eye witness of the period and a close associate of many of the major players. Both Macaulay and Warren were religiously inspired and believers in the equality of the sexes, whereas Thomas Paine, who because of his secularism replaces Locke in Israel's narrative as the quintessential voice of democracy, could not bring himself to extend equality to women. The women-being 
firm Protestant believers in their spiritual equality with men -set out, unsuccessfully as it turned out, to be accorded equal status with men as authoritative recorders of historical events. This history, like so many others, fails to acknowledge their efforts. Macaulay is briefly mentioned in passing. Warren is completely omitted. This constitutes a backsliding from the eighteenth century when both wrote to considerable acclaim.

Israel's schema prevents him from acknowledging the extent to which the American revolutionaries saw themselves as heirs of the mid-seventeenth century English Republicans. Initially the colonists were not clearly democratic republicans, but represented themselves as loyal subjects of the crown, whose traditional British liberties were being undermined, as Warren's account makes clear. Her version of events is confirmed by the recently published Correspondence of Catharine Macaulay (Oxford, 2019). Most problematically, Israel's simplistic association of secularism with radical political progress prevents him from questioning whether a secular faith in reason is not itself just the modern manifestation of Protestant faith in the idea that God has illuminated all with the candle of his light. His framework truly creaks when, in the last chapters, he has to acknowledge the emergence of socialism as a new alternative to the democratic republicanism that he represents as the political form that is rationally justifiable from a secular point of view. Socialism, he admits, is equally secular (551). It arises just when faith that God has provided all humans with a faculty of reason, capable of converging on moral and political principles, is dashed by the failure of the demos to follow the lead of the intellectual elite. Israel provides a very nice account of the disillusionment that followed the democratic elections in France, of April 1848, when 'the rooted biases of less educated proved an insuperable barrier to the radical tendency' (562). Universal male suffrage, paradoxically, resulted in a legislature dominated by clergy, landowners, and nobles. Just as, more recently, democratic elections in Egypt resulted in government dominated by individuals opposed to liberal democratic ideals, so, in France, 150 years earlier, the people perversely failed to appreciate the progressive principles of their 'enlightened' secular leaders.

In writing his impressive series of histories of the origins of the liberal democratic order, Israel set out to counter popular Marxist historiography, which underplays the influence of ideas in the genesis of historical events. He also set out to counter the more recent, post-modern rejection of the rational basis of liberal, democratic principles. He has certainly achieved the first of these aims. He is far less successful in the second. He completely fails to come to terms with the post-modern claim that faith in reason is itself an onto-theology. From a post-modern point of view, monistic, Spinozistic pantheism, which assumes a universe governed by rationally comprehensible ethical laws determinable with geometrical precision, is as much an onto-theology as is dualistic Cartesianism, which argues that a good God would not have made us subject to subjectively compelling conclusions that are false. Empiricism and the failure of logicism undermine both versions of rationalism. If one is to restore the enlightenment faith that a liberal, democratic republicanism is the best form of government and more rationally justifiable than other systems, one needs to demonstrate that faith in reason is not just onto-theology in disguise, and this is a challenge with which Israel simply fails to engage.

\section{Competing Interests}

The author has no competing interests to declare. 
How to cite this article: Green, Karen. 2019. "Review of Jonathan Israel, The Expanding Blaze. How the American Revolution Ignited the World, 1775-1848, Princeton: Princeton University Press, 2017, 755 pp, HB." Redescriptions: Political Thought, Conceptual History and Feminist Theory 22(1): 71-74. DOl: https://doi.org/10.33134/rds.305

Submitted: 15 October 2019 Accepted: 15 October 2019 Published: 03 December 2019

Copyright: (c) 2019 The Author(s). This is an open-access article distributed under the terms of the Creative Commons Attribution 4.0 International License (CC-BY 4.0), which permits unrestricted use, distribution, and reproduction in any medium, provided the original author and source are credited. See http://creativecommons.org/licenses/by/4.0/.

Hedescriptions: Political Thought, Conceptual History and

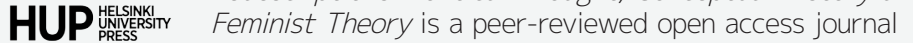

OPEN ACCESS $\precsim$ published by Helsinki University Press. 